\title{
Immunoregulatory T Cell Function in Multiple Myeloma
}

\author{
H. Ozer, T. Han, E. S. Henderson, A. Nussbaum, and D. Sheedy, Section \\ of Tumor Immunology, Department of Medical Oncology, Roswell Park \\ Memorial Institute, Buffalo, New York 14263
}

A B S T RACT Multiple myeloma is a malignancy characterized by uncontrolled monoclonal B cell differentiation and immunoglobulin production. In most instances, there is concomitant reduction in polyclonal differentiation and immunoglobulin synthesis both in vivo and in vitro. In in vitro pokeweed mitogen-induced $B$ cell differentiation assays, proliferation and polyclonal immunoglobulin secretion optimally requires $\mathrm{T}$ cell help and can be inhibited both by monocytes and suppressor $\mathrm{T}$ cells. Helper function and monocyte-mediated suppression are relatively radioresistant whereas $T$ suppressor function is sensitive to 2,000 rad $\mathrm{x}$-irradiation. We have examined myeloma $T$ cell subset function in this assay using recombinations of isolated patient and normal B cells, $T$ cells, and $T$ cell subsets. Monocytes were removed by a carbonyl iron ingestion technique, normal and myeloma $\mathrm{T}$ cells were fractionated on the basis of $\mathrm{Fc}$ receptors for immunoglobulin (Ig)G (T $\gamma$ ) or IgM (T $\mu$ or T non- $\gamma$ ), and proliferation and IgG secretion after co-culture determined by $\left[{ }^{3} \mathrm{H}\right]$ thymidine incorporation and radioimmunoassay, respectively. Myeloma B cells demonstrate quantitatively and qualitatively normal blastogenic responses and are appropriately regulated by either autologous or allogeneic $\mathrm{T}$ helper and suppressor subsets. Despite normal proliferation, however, myeloma B cells remain deficient in subsequent differentiation and immunoglobulin secretion even when co-cultured in the absence of monocytes or suppressor $\mathrm{T}$ cells and the presence of normal helper cells. Myeloma $\mathrm{T}$ cell populations, in contrast, are entirely normal in helper capacity over a range of $\mathrm{T}: \mathrm{B}$ ratios but are markedly deficient in radiosensitive and concanavalin A-induced suppressor activity. $\mathrm{T}$ suppressor cell dysfunction in multiple myeloma is apparently due to a deficit in the $T$ non- $\gamma$ suppressor subset, whereas $\mathrm{T} \gamma$ cells, although proportionately reduced, are functionally normal. This unique $\mathrm{T}$ suppressor deficit reflects the heterogeneity of suppressor mechanisms in this disease and may represent a compensatory

Received for publication 12 May 1980 and in revised form 10 October 1980. response to the monoclonal proliferation or the involvement of regulatory $T$ cells in the pathogenesis of the malignancy.

\section{INTRODUCTION}

Multiple myeloma $(\mathrm{MM})^{1}$ is clinically defined as a malignant plasma cell proliferation resulting in bone marrow replacement, paraprotein production, osteolytic bone lesions, decreased polyclonal immunoglobulin (Ig) synthesis, and a concomitant increase in susceptibility to certain bacterial pathogens $(1-3)$. The immunodeficiency of myeloma is distinct from that of other malignancies in that both myeloma patients and mice bearing plasmacytomas exhibit impaired primary responses to antigenic challenge, whereas secondary responses as well as delayed hypersensitivity are less severely affected (1,3-7). A variety of hypotheses have been suggested to explain impaired host polyclonal Ig synthesis in both multiple myeloma and murine plasmacytomas including the alteration of antigenbinding cells by infective RNA subunits from malignant plasma cells (8), the influence of mitotic inhibitors or chalones that block polyclonal B cell differentiation (9), and the presence of circulating immunosuppressive factors produced by murine plasmacytoma cells (10). In contrast to studies attributing the depressed primary responses and Ig levels to an immunosuppressive product of the expanding population of tumor cells, Broder et al. (11) originally suggested that a potential abnormality of host immunoregulatory cells might be involved in the immunodeficiency of myeloma in man (11). They demonstrated suppressor activity by unfractionated myeloma peripheral leukocytes that was mediated primarily by phagocytic mononuclear cells and not by $T$ lymphocytes. Similar adherent cell suppressor mechanisms have been demonstrated in the murine plasmacytoma model $(5,12)$ and in addition an augmenting role for tumor cell factors on macrophage-

\footnotetext{
${ }^{1}$ Abbreviations used in this paper: $\mathrm{BRBC}$, bovine erythrocytes; FCS, fetal calf serum; MM, multiple myeloma; $n$, normal cells; PWM, pokeweed mitogen; RFC, rosette-forming cells; sIg, surface immunoglobulin; SRBC, sheep RBC.
} 
mediated suppression has been suggested. Knapp and Baumgartner (13), however, demonstrated that adherent cell suppressor activity is present in healthy individuals as well as myeloma patients, suggesting that monocyte/ macrophage-mediated suppression of B cell differentiation is neither a disease-specific phenomenon nor an explanation of decreased in vivo or in vitro polyclonal Ig synthesis in myeloma. Paglieroni and MacKenzie (14), in addition, have shown that a significant amount of suppressor activity in myeloma patients is present in a nonadherent lymphoid subset

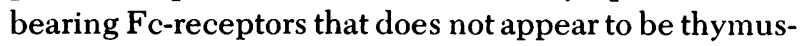
derived as defined by the presence of receptors for sheep erythrocytes $(14,15)$. This suppressor activity can be demonstrated for antigen-induced blast transformation and autologous or allogeneic B cell differentiation as well as on mixed lymphocyte responses by allogeneic normal $\mathrm{T}$ cells. We have extended these studies of Ig-producing deficits in myeloma by examining the functional regulatory capacity of MM Ty and $T$ non- $\gamma$ subsets on patient and normal $B$ cell differentiation. The data presented here confirm Paglieroni and MacKenzie's observation $(14,15)$ that myeloma B cell differentiation is markedly impaired even in the absence of suppressor $\mathrm{T}$ cells or monocytes. In addition, new data presented here demonstrate: $(a)$ MM B cell differentiation cannot be augmented in the presence of either myeloma or normal $\mathrm{T}$ helper subsets, (b) $\mathrm{T}$ helper activity in these patients in nonetheless functionally intact over a range of $\mathrm{T}: \mathrm{B}$ ratios, and $(c)$ unlike the leukemic cell population in most patients with chronic lymphocytic leukemia, the early stage of peripheral $B$ cell differentiation in $M M, T$ cellregulated B cell proliferation, is virtually normal, whereas $(d)$ a specific $T$ suppressor abnormality can be identified in these patients for $\mathrm{T}$ cell-regulated IgG secretion. The suppressor deficit in multiple myeloma is further shown to be confined to the $T$ non- $\gamma$ suppressor cell subset that demonstrated sensitivity to $2,000 \mathrm{rad} x$-irradiation and is inducible in the presence of concanavalin A.

\section{METHODS}

Patient population. 23 different healthy volunteer agematched donors who were receiving no medication were used as controls. A total of 21 different patients with MM between 48 and $63 \mathrm{yr}$ of age were included in this study. The diagnosis of multiple myeloma was confirmed by the presence of at least two of the following criteria: $(a)$ plasma cells constituting $>20 \%$ of the total nucleated cell population of aspirated bone marrow without other known causes; $(b)$ a monoclonal serum or urine gamma globulin peak on immunoelectrophoresis in combination with reduction in other serum Ig, and (c) osteolytic lesions in the skull, vertebral column, or pelvis. Of the 21 patients examined, 14 had not received prior therapy and were newly diagnosed. The remaining seven patients had previously received intermittent therapy with alkylating agents and corticosteroids, however these patients were sampled at least 6-8 wk following completion of their last drug cycle or were off chemotherapy altogether. 18 of the myeloma patients examined had IgG components and three had IgA; none had macroglobulinemia or light chain diseases.

Isolation of lymphocyte populations. Peripheral leukocyte populations were obtained from buffy coats separated either by leukopheresis of both patients and normal volunteers with a Haemonetics model 30 Cell Separator (Haemonetics Corp., Natick, Mass.) or by gravity sedimentation of $500 \mathrm{ml}$ of citrated blood from some volunteer donors. No differences in surface markers or in vitro functional capacity of lymphocytes obtained by either method were apparent in our assays. Informed consent was routinely required before patients were entered into this study. Phagocytic mononuclear cells were depleted by diluting each buffy coat $1: 2$ with medium containing carbonyl iron (Technicon Instrument Co., Tarrytown, N. Y.) in 50-ml aliquots, and incubating the mixture for 60 min with gentle continuous agitation. Each leukocyte population was then layered in $10-\mathrm{ml}$ aliquots on $3 \mathrm{ml}$ FicollHypaque density gradients (Pharmacia Fine Chemicals, Inc. Piscataway, N. J.), in 15-ml siliconized glass tubes and centrifuged $40 \mathrm{~min}$ at $400 \mathrm{~g}$. The interface layer was resuspended in RPMI 1640 (Gibco Laboratories, Grand Island Biological Co., Grand Island, N. Y.) and washed two times. Viability of the purified lymphocyte populations was routinely $>95 \%$ and monocyte contamination was always $<2 \%$ by nonspecific esterase staining and latex bead ingestion.

E rosette positive $\left(E^{+}\right)$and negative $\left(E^{-}\right)$lymphocyte populations were obtained by rosetting with sheep erythrocytes (SRBC) that had been treated with 2-aminoethylisothiouronium bromide according to the method of Kaplan and Clark (16). 2Aminoethylisothiouronium bromide-treated sheep erythrocytes were washed twice in RPMI 1640 containing $10 \%$ fetal calf serum (FCS) and antibiotics, and mixed with lymphocyte suspensions at a ratio of 50 SRBC: 1 lymphocyte in $15-\mathrm{ml}$ conical siliconized glass tubes. These mixtures were centrifuged for $8 \mathrm{~min}$ at $200 \mathrm{~g}$ and incubated $18 \mathrm{~h}$ at $4^{\circ} \mathrm{C}$. The pellets were resuspended gently, rosette-forming cells (RFC) were enumerated, and the $\mathrm{E}^{+}$population sedimented on Ficoll-Hypaque at $400 \mathrm{~g}$ for $40 \mathrm{~min}$. SRBC were removed by brief hypotonic lysis and the pellets resuspended in $3 \%$ saline to isotonicity. $\mathrm{E}^{+}$and $\mathrm{E}^{-}$populations were washed twice in supplemented RPMI 1640 and kept at $4^{\circ} \mathrm{C}$. Purity of these and other populations were determined by enumerating surface Ig-positive $\left(\mathrm{sIg}^{+}\right)$cells with rabbit anti-human $\mathrm{F}\left(\mathrm{ab}^{\prime}\right)_{2}$-coupled bovine erythrocytes (BRBC, Gibco Laboratories) according to the method of Gold and Fudenberg (17) as previously described (18). Complement receptor-positive lymphocytes were detected by a similar rosetting assay using BRBC sensitized with anti-BRBC IgG and which had been incubated with a 1:10 dilution of fresh human serum previously absorbed at $4^{\circ} \mathrm{C}$ with BRBC.

Sepuraıwn of T $\gamma$ and T non- $\gamma$ subpopulations. EA.G ${ }^{+}(T \gamma)$ cells were isolated by positive selection with BRBC coated with the IgG fraction of rabbit anti-BRBC antibody (N. L. Cappel Laboratories, Cochranville, Pa.). This antibody was screened for titer and class specificity and further purified on Sephadex G-150 columns if necessary. T $\gamma$ RFC were prepared by a modification of the technique of Moretta et al. (19). Briefly, washed BRBC were incubated with a 1:70 dilution of anti-BRBC IgG for $30 \mathrm{~min}$ at $37^{\circ} \mathrm{C}$ in normal saline with occasional mixing, washed twice in saline, and stored at $4^{\circ} \mathrm{C}$ for use within 4 d. EA.G ${ }^{+}$RFC were prepared by a 2 -h incubation of the $\mathrm{E}^{+}$population with IgG-coated $\mathrm{BRBC}$ at 150 BRBC: 1 lymphocyte in RPMI 1640 with $10 \%$ FCS. The rosettes were resuspended with extremely gentle agitation, layered on Ficoll-Hypaque gradients, and centrifuged for 15 
min at $200 \mathrm{~g}$. EA.M $\mathrm{M}^{+}$RFC $(\mathrm{T} \mu)$ were enumerated in an analogous manner using an 18 - $\mathrm{h}$ incubation at $37^{\circ} \mathrm{C}$ with BRBC coated with a 1:70 dilution of rabbit anti-BRBC IgM antibodies (N. L. Cappel Laboratories) purified as necessary.

Co-culture methods. IgG produced by isolated subpopulations and in co-culture experiments was determined by a modification of the technique described by Gailani et al. (20). Lymphocyte populations were adjusted to a final concentration of $2 \times 10^{6}$ cells per $\mathrm{ml}$ in RPMI 1640 supplemented with glutamine, $0.1 \mathrm{ng} / \mathrm{ml}$ gentamicin and previously screened, heat-inactivated $10 \%$ FCS. The cell suspensions were incubated in flat-bottomed microtiter plates (Linbro Chemical Co., Hamden, Conn.) for $7 \mathrm{~d}$ at $37^{\circ} \mathrm{C}$ in a humidified $5 \% \mathrm{CO}_{2}$ atmosphere. In co-culture experiments, ratios of $\mathrm{B}: \mathrm{T}$ cells were maintained at 1:2 while $T$ cell subpopulations were recombined in equal ratios unless otherwise noted such as in the titration experiments. The total well volume was $350 \mu \mathrm{l}$. In some experiments, $T$ cells were irradiated with 2,000 rad x-irradiation from a General Electric Maxitron 250 x-ray machine (General Electric Co., Schenectady, N. Y.) using $0.25-\mathrm{mm} \mathrm{Cu}$ and $1-\mathrm{mm} \mathrm{Al} \mathrm{filters.} \mathrm{Proliferation} \mathrm{responses}$ were determined on day 3 of culture following a $6-\mathrm{h}$ pulse with $2 \mu \mathrm{Ci} /$ well of tritiated thymidine (TdR) (sp act $6.7 \mathrm{Ci} /$ $\mathrm{mmol}$ ) and subsequent harvesting of the entire contents of the well for liquid scintillation counting. Radioimmunoassay was performed on day 7 by a double antibody technique using $200 \mu \mathrm{l}$ of supernate from each well following centrifugation of the plate. Affinity-column purified human IgG, previously shown to be specific by gel double diffusion and immunoelectrophoresis, was labeled with $1 \mathrm{mCi}$ of ${ }^{125} \mathrm{I}$ using a chloramine-T method. The dilution of anti-IgG that bound $60 \%$ of a suitable amount of labeled IgG was determined. Anti-IgG was prepared by multiple rabbit immunizations with purified IgG protein followed by affinity column purification of the antibody. Antigen-antibody dilution curves were constructed for an antigen range of 1 to $30 \mathrm{ng}$ and a 1:8,000 dilution of antiserum. The amount of goat anti-rabbit Ig added to precipitate the rabbit Ig was twice the equivalence amount. From 10 to $100 \mu$ l of culture supernate or standard was added to $20 \mu \mathrm{l}$ of anti-IgG for $1 \mathrm{~h}$ at $37^{\circ} \mathrm{C}$ in $10 \times 75-\mathrm{mm}$ plastic Falcon tubes (Falcon Labware, Div. Becton, Dickinson \& Co., Oxnard, Calif.) after which $10 \mu \mathrm{l}$ of goat antirabbit Ig was added and the mixture incubated for $1 \mathrm{~h}$ at $37^{\circ} \mathrm{C}$. After overnight incubation at $4^{\circ} \mathrm{C}, 1.0 \mathrm{ml}$ of $0.01 \mathrm{M}$ Tris, $\mathrm{pH}$ 7.0-7.4, was added to each tube. The tubes were centrifuged at $4^{\circ} \mathrm{C}$ and $2,000 \mathrm{~g}$ for $20 \mathrm{~min}$, after which the supernate was discarded, and the pellet counted. Standards were prepared in $0.01 \mathrm{M}$ Tris with $1 \%$ bovine serum albumin. The binding of labeled IgG could be shown to be $>90 \%$ specifically inhibited by cold IgG.

Con A-induced suppression of IgG secretion. T lymphocyte populations or $T$ cell subsets from both patients and normal donors were activated in the presence of $5 \mu \mathrm{g} / \mathrm{ml}$ concanavalin A (Con A) (Calbiochem Behring Corp., American Hoechst Corp., San Diego, Calif.) for 48 h in RPMI 1640 supplemented with $10 \%$ FCS, $200 \mathrm{mM}$ L-glutamine, antibiotics, and $25 \mathrm{mM}$ Hepes buffer at a concentration of $4 \times 10^{6}$ cells/ $\mathrm{ml}$. Untreated control cells were cultured in an identical fashion without Con A. Following activation, cultured T cells were washed three times, adjusted to a concentration of $2 \times 10^{6} \mathrm{cells} / \mathrm{ml}$, and incubated in standard culture media for $20 \mathrm{~min}$ in the presence of $25 \mu \mathrm{g} / \mathrm{ml}$ mitomycin-C (Bristol Laboratories, Syracuse, N. Y.). These activated T cells and subsets were subsequently washed four times, readjusted to $2 \times 10^{6} \mathrm{cells} / \mathrm{ml}$ and added to normal allogeneic irradiated T and unirradiated $\mathrm{T}$ co-cultures to determine Con A-induced suppression of maximal IgG secretion. In preliminary experiments, 0.3 M $\alpha$-methyl-D-mannoside (Sigma Chemical
Co., St. Louis, Mo.) was included in the wash, but was found not to influence the results significantly and reported experiments were performed in the absence of $\alpha$-methyl-mannoside. The percent suppression of total IgG secretion was calculated according to the following formula:

percent suppression

$$
=\frac{\text { IgG secretion by } B+T x+\text { cultured } T}{\text { IgG secretion by } B+T x+\text { cultured } T \text { Con } A}=100 \text {. }
$$

where B + Tx co-cultures were performed using normal autologous cell populations and allogeneic cultured $T$ cells as controls. T Con A cells consisted of allogeneic normal or patient $\mathrm{T}$ cells and subsets incubated $48 \mathrm{~h}$ with Con A. Total cocultures contained $1 \times 10^{5}$ cells of each subpopulation.

Statistical analysis. Data are presented as either ranges or means \pm SEM of the total patient and normal donor populations for both $\left[{ }^{3} \mathrm{H}\right]$ thymidine incorporation and IgG production. Individual experiments were performed with paired patient and normal samples in triplicate in each instance, and the individual means were used to calculate the group means as presented. The statistical significance of the difference between mean values in the various groups was determined by the student's $t$ test and for individual pairs by the paired $t$ test. A $P$ value of $<0.05$ was considered to represent a significant result and is so indicated in the figures and tables.

\section{RESULTS}

Surface markers of lymphocyte subsets. Myeloma lymphocyte populations were readily separable into $\mathrm{E}^{+}$and $\mathrm{E}^{-}$populations with at least $95 \%$ purity in every instance by repeat surface marker analysis (Table I). The $\mathrm{E}^{-}$population was greatly enriched for sIgbearing cells and cells bearing complement receptors. In both patients and normal individuals, an average of $70 \%$ of this population is identifiable as B lymphocytes by the presence of sIg. The remainder of the $\mathrm{E}^{-}$ population from normal donors consists of a very small proportion of contaminating $\mathrm{E}^{+} \mathrm{T}$ cells $(3-5 \%)$ and a null population which is heterogeneous for Ia, complement and Fc receptors, but highly active in two in vitro assays: antibody-dependent cellular cytotoxicity and natural killing $(18,21), \gamma \mathrm{FcR}^{+}$and $\mu \mathrm{FcR}^{+}$subsets of $\mathrm{T}$ lymphocytes could also be easily identified and the $\mathrm{T} \gamma$ fraction readily separated from both myeloma and normal $\mathrm{T}$ lymphocyte populations. The proportions of total $\mathrm{T}$ cells bearing receptors for either IgG or IgM were equally variable in patients and normal individuals and $\sim 90-95 \%$ of the total $\mathrm{T}$ population was found to bear $\mathrm{F}_{\mathrm{c}}$ receptors for one or the other class of Ig. Repeat Fc-rosetting following positive selection demonstrated enrichment to at least $65-90 \%$ of cells bearing the $\mathrm{Fc}$ receptor specifically isolated, whereas $<3 \%$ of either subset bore the nonselected $\mathrm{Fc}$ receptor. Thus both the $\mathrm{T} \gamma$ and $\mathrm{T} \mu$ subset could be isolated with $>95 \%$ purity by negative criteria although masking of the receptors during the separation apparently prevents repeat rosetting of a proportion of 
TABLE I

Surface Characteristics of Normal and Myeloma Lymphocyte Subsets

\begin{tabular}{|c|c|c|c|c|c|}
\hline Lymphocyte subset & $\begin{array}{c}\text { Percent } \\
\mathrm{E}^{+}\end{array}$ & $\begin{array}{l}\text { Percent } \\
\operatorname{sig}^{+}\end{array}$ & $\begin{array}{l}\text { Percent } \\
\text { EAC }^{+}\end{array}$ & $\begin{array}{c}\text { Percent } \\
\gamma \mathrm{FcR}^{+}\end{array}$ & $\begin{array}{l}\text { Percent } \\
\mu \mathbf{F} \mathbf{R}^{+}\end{array}$ \\
\hline \multicolumn{6}{|l|}{ Normal donors $(n=14)$} \\
\hline Unfractionated PBL & $63-80$ & $5-18$ & $7-28$ & - & - \\
\hline $\mathrm{E}^{-}(\mathrm{B}$ cells + null cells $)$ & $3-5$ & $68-92$ & $39-76$ & - & - \\
\hline $\mathrm{E}^{+}(\mathrm{T}$ cells $)$ & $94-99$ & $0-3$ & $2-6$ & $\begin{array}{c}16-24^{*} \\
\text { Mean }=19.3 \pm 2.3 \mathrm{SD}\end{array}$ & $17-62$ \\
\hline EA.G ${ }^{+}(\mathrm{T} \gamma)$ & $92-98$ & $<2$ & $<2$ & $67-89 \ddagger$ & $<2$ \\
\hline EA.G ${ }^{-}\left(T_{\text {non }} \boldsymbol{\gamma}\right)$ & $94-99$ & $<2$ & $2-4$ & $0-3$ & $54-82 \ddagger$ \\
\hline \multicolumn{6}{|l|}{ Myeloma patients $(n=13)$} \\
\hline Unfractionated PBL & $64-80$ & $7-21$ & $5-22$ & - & - \\
\hline $\mathrm{E}^{-}(\mathrm{B}$ cells + null cells $)$ & 4 & $64-87$ & $40-82$ & - & - \\
\hline $\mathrm{E}^{+}(\mathrm{T}$ cells $)$ & $95-99$ & $0-3$ & $<2$ & $\begin{array}{c}3-15^{*} \\
\text { Mean }=10.9 \pm 3.9 \mathrm{SD}\end{array}$ & $26-60$ \\
\hline EA.G $^{+}(\mathrm{T} \gamma)$ & $94-98$ & $<2$ & $<2$ & $63-88 \rrbracket$ & $<2$ \\
\hline EA.G- $(\mathrm{T}$ non $\gamma)$ & $95-99$ & $<2$ & $<2$ & $<2$ & $54-84$ \\
\hline
\end{tabular}

* The difference between mean percent EA.G ${ }^{+}$cell numbers in myeloma and normal is significant by both Student $t$ and paired $t$ tests $(P<0.05)$.

$\$$ Determined by a second rosetting. Purity of separated rosette-forming cells after FicollHypaque gradient separation and prior to BRBC lysis was always $>95 \%$.

PBL, peripheral blood leukocytes.

each subset following isolation. A minor but consistent difference in numbers of $\mathrm{T} \gamma$ cells in patient $\mathrm{T}$ populations compared to normal donor $\mathrm{T}$ cells could be identified. Myeloma $\mathrm{T} \gamma$ populations were proportionately lower (mean $10.9 \pm 3.9 \% \mathrm{SD}$ ) than normal $\mathrm{T} \gamma$ populations (mean $19.3 \pm 2.3 \% \mathrm{SD} ; P<0.05$ ). All other surface markers, including $\mu \mathrm{FcR}$, were essentially identical in myeloma and normal lymphocyte populations. Despite high concentrations of $\mathbf{M}$ components and a concomitant reduction in serum polyclonal Ig in our patient population, there were no apparent differences in absolute numbers or porportions of circulating $\mathrm{sIg}^{+}$cells in patients compared to normal donors.

$T$ cell-regulated IgG production by normal and myeloma B cells. The in vitro production of IgG by isolated normal and myeloma lymphocyte populations after pokeweed mitogen (PWM) stimulation was determined in the absence of monocytes $(<2 \%)$ for 14 normal donors and 13 myeloma patients. IgG secretion after a 7-d incubation period is expressed as nanograms IgG per milliliter, which was equivalent in our culture system to nanograms $/ 3 \times 10^{5}$ total lymphocytes or nanograms per liter $\times 10^{5} \mathrm{~B}$ cells cultured (Table II).

Isolated $\mathrm{T}$ and $\mathrm{B}$ populations from normal donors and patients produced only minimal amounts of IgG while co-culture of normal $\mathrm{T}$ and $\mathrm{B}$ populations produced $\sim 1,300 \mathrm{ng} / \mathrm{ml}$. In contrast, monocyte-depleted myeloma $\mathrm{T}$ and $\mathrm{B}$ co-cultures were significantly depressed
$(P<0.005)$ in their ability to produce IgG. In an initial attempt to determine the role of myeloma $T$ cell regulation of polyclonal Ig synthesis, we cultured autologous $\mathrm{B}$ and $\mathrm{T}$ cells after prior $\mathrm{x}$-irradiation of the total $T$ populations. Moderate doses (1-2,000 rad) $x$ irradiation have been previously demonstrated to selectively abrogate polyclonal suppressor $\mathrm{T}$ cell function in a similar assay system (22), while adherent suppressor cells are relatively more radioresistant (13).

\section{TABLE II}

$T$ Cell-Regulated IgG Production by Peripheral B Cells from Normal Donors and Myeloma Patients

\begin{tabular}{|c|c|c|}
\hline \multirow{2}{*}{$\begin{array}{l}\text { Composition of } \\
\text { cells cultured } \\
\text { (PWM added } \\
\text { at } 1: 200)\end{array}$} & \multicolumn{2}{|c|}{ IgG secretion $(\mathrm{ng} / \mathrm{ml} / 7$ days \pm SEM) } \\
\hline & $\begin{array}{l}\text { Normal donors } \\
\quad(n=14)\end{array}$ & $\begin{array}{l}\text { Myeloma patients } \\
\qquad(\mathrm{n}=13)\end{array}$ \\
\hline $\mathrm{T}$ cells alone & $22 \pm 21$ & $25 \pm 14$ \\
\hline B cells alone & $133 \pm 29$ & $191 \pm 66$ \\
\hline$B+T$ & $1,295 \pm 120$ & $172 \pm 42$ \\
\hline$B+T x$ & $1,987 \pm 317^{*}$ & $236 \pm 66$ \\
\hline$M M-T+B n$ & $1,434 \pm 150$ & \\
\hline$M M-T x+B n$ & $1,488 \pm 177$ & \\
\hline
\end{tabular}

n, normal. $x, 2,000$ rad $x$-irradiation. Ratios of co-culture: $\mathrm{B}: \mathrm{T}=1 \times 10^{5}: 2 \times 10^{5}$.

* The mean IgG production following irradiation of autologous $T$ cells was significantly increased over nonirradiated $T$ cells $(P<0.05)$. 


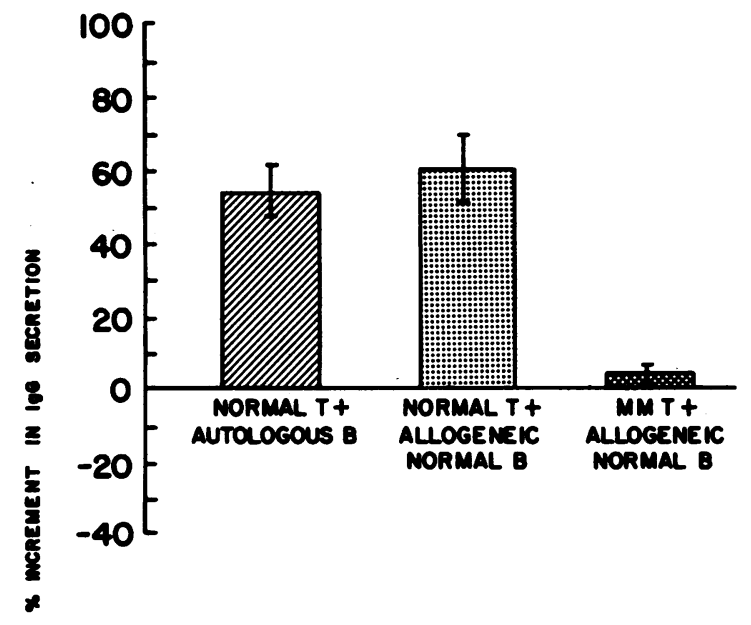

FIGURE 1 Radiosensitive suppressor $\mathrm{T}$ cell function in $\mathrm{MM}$ : comparison of normal B cell IgG secretion after $7 \mathrm{~d}$ in coculture with untreated and irradiated $T$ cells from normal donors and myeloma patients. Results are expressed as the percent increment in total IgG secreted in co-cultures containing irradiated $(2,000 \mathrm{rad}) \mathrm{T}$ cells $\pm \mathrm{SEM}$. Culture conditions are described in the text.

IgG production by co-cultures of B plus irradiated autologous $T$ cells from normal donors was significantly increased over nonirradiated $\mathrm{T}$ cells $(1,987 \pm 317 \mathrm{ng}$ vs. $1,295 \pm 120 \mathrm{ng}, P<0.05)$. Only a very minor and insignificant increment in mean IgG production was observed in co-cultures of myeloma $B$ cells and irradiated myeloma $\mathrm{T}$ cells $(236 \pm 66 \mathrm{ng}$ vs. $172 \pm 42 \mathrm{ng}$, $P>0.10)$ and in a number of patients a decrease in IgG secretion could be demonstrated after $x$-irradiation of co-cultured $T$ cells. In an effort to assess the helper and suppressor capacity of myeloma $\mathrm{T}$ cells, co-cultures of patient $T$ and allogeneic normal. $B$ cells were compared with and without $\mathrm{x}$-irradiation (Table II). Myeloma T cells were able to help normal B cell IgG production virtually as well as autologous $T$ cells; however, $x$ irradiation of the myeloma $T$ population did not result in any increment in IgG production by normal B cells as was consistently demonstrated with irradiated normal $T$ cells. This difference is not simply the result of allogeneic effects since, as shown in Fig. 1, there are significant increases in IgG production with prior $\mathrm{T}$ cell $x$-irradiation whether the differentiating $B$ cell population is autologous or allogeneic. In order to exclude the possibility that a more subtle deficiency in $\mathrm{T}$ helper activity might be involved in $\mathrm{MM}$, we also examined $\mathrm{T}$ cell help for Ig secretion using serial dilutions of normal and patient $T$ cells co-cultured with a constant $1 \times 10^{5}$ normal $B$ cells. In the three separate patients and normal controls shown in Fig. 2, no significant difference in helper function could be identified even at $T: B$ ratios of 0.1 . The radiation-induced increment in IgG secretion was evident only for normal donor $T$ populations at $\mathrm{T}: \mathrm{B}$ ratios of 0.5 or greater and was nonexistent in these three myeloma patients. Thus, although myeloma $T$ cells are relatively normal in helper function, we were unable to demonstrate the expected radiosensitive suppressor activity by total myeloma $T$ lymphocyte populations.

Immunoregulatory capacity of normal and myeloma $T$ cell subsets on autologous B cell function. This

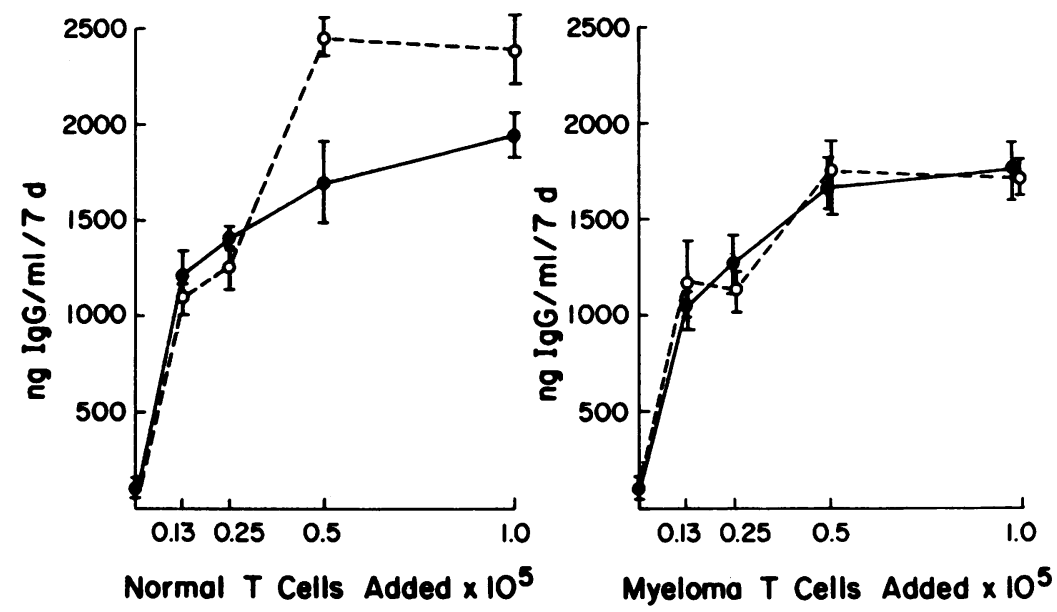

FIGURE 2 Comparison of myeloma and normal donor $x$-ray-induced increments in IgG secretion with varying $T: B$ ratios. A constant number $\left(1 \times 10^{5}\right)$ of $B$ cells was co-cultured for $7 \mathrm{~d}$ with varying numbers of $\mathrm{T}$ cells from normal allogeneic donors or myeloma patients. Solid lines represent the addition of unirradiated $T$ cells, whereas dashed lines represent $T$ cells added after 2,000 rad $x$-irradiation. Results are expressed as means for three individual normal donor and patient co-cultures \pm SEM. 
apparent deficiency in radiosensitive $T$ suppressor activity in myeloma $\mathrm{T}$ cell populations could result either from the proportional decrease in the $\mathrm{T} \gamma$ subset within the total $\mathrm{T}$ cell population or from a functional abnormality of the suppressor subsets. In order to determine which of these possibilities was contributing to the observed suppressor abnormality, we compared isolated $\mathrm{T} \gamma$ and $\mathrm{T}$ non- $\gamma$ cells from myeloma patients in 72-h thymidine incorporation and 7-d B cell differentiation assays. Table III demonstrates the results obtained in 14 healthy subjects and 13 myeloma patients for autologous $\mathrm{B}$ and $\mathrm{T}$ cell subsets.

As with IgG secretion, isolated B cells from either patients or normal donors exhibited minimal blastogenic responses to PWM. Total T cells responded well to PWM and the T non- $\gamma$ subset demonstrated an increase in mean thymidine incorporation over unfractionated $T$ cells. $T \gamma$ cells, on the other hands, were not only poorly responsive to PWM, but were capable of suppressing the blast response of an equal number of $\mathrm{T}$ non- $\gamma$ cells by nearly $50 \%$. Irradiated T cells cultured alone or in the presence of irradiated B cells still demonstrated a small blastogenic response, although significantly below that of $\mathrm{B}+\mathrm{Tx}$ co-cultures. Aside from an insignificant difference in mean change in counts per minute by myeloma $\mathrm{T}$ and $\mathrm{B}$ cell populations compared with normal, there were no qualitative or quantitative differences between patient and normal lymphocytes in blast responsiveness. When $\mathrm{T}$ and $\mathrm{B}$ cells were co-cultured, thymidine incorporation was more than doubled in both normal and patient populations compared to either population cultured alone. As has been previously described (19) only T non- $\gamma$ cells provided help for both thymidine incorporation and IgG secretion. The T $\gamma$ subset did not allow either B cell proliferation or antibody synthesis, and in coculture with $\mathrm{T}$ non- $\gamma$ and $\mathrm{B}$ cells, suppressed both blast responsiveness and Ig secretion. Myeloma patient blast responses appeared to be well within the normal range for $B$ and $T$ cooperative responses, suggesting that myeloma $\mathrm{B}$ cells were actively synthesizing DNA; however, the amount of IgG subsequently secreted by patient B cells was markedly depressed even in the complete absence of either $\mathrm{T}$ suppressor cells or monocytes.

Although a low to moderate dose $(2,000 \mathrm{rad}) \mathrm{x}$ irradiation of the $T$ non- $\gamma$ subset resulted in a decrease in total thymidine incorporation for $B$ and $T$ cocultures, a radioresistant increment in helper activity for Ig secretion was demonstrable for this subset from

TABLE III

Immunoregulatory Capacity of Normal and Myeloma T Cell Subsets

\begin{tabular}{|c|c|c|c|c|}
\hline $\begin{array}{l}\text { Composition of } \\
\text { co-culture }\end{array}$ & & $\begin{array}{c}\text { Normal donors, } \\
n=14\end{array}$ & & $\begin{array}{l}\text { Myeloma patients, } \\
\quad n=13\end{array}$ \\
\hline \multirow[t]{2}{*}{ PWM added at $1: 200$} & & {$\left[{ }^{3} \mathrm{H}\right] \mathrm{TdR}$ incorporation } & & {$\left[{ }^{3} \mathrm{H}\right] \mathrm{TdR}$ incorporation } \\
\hline & & Mean $\triangle C P M+S E M^{*}$ & & Mean $\triangle C P M+S E M$ \\
\hline B cells alone & & $2,543 \pm 1,310$ & & $1,864 \pm 1,436$ \\
\hline $\mathrm{T}$ cells alone & & $8,005 \pm 1,361$ & & $7,160 \pm 1,431$ \\
\hline $\mathrm{T}$ non- $\gamma$ cells alone & & $10,114 \pm 2,372$ & & $8,904 \pm 1,215$ \\
\hline $\mathrm{T}$ cells alone & & $1,426 \pm 1,838$ & & $520 \pm 297$ \\
\hline$T$ non $\gamma+T \gamma$ cells & & $5,738 \pm 1,321$ & & $4,977 \pm 732$ \\
\hline xT alone & & $1,421 \pm 1,221$ & & $1,583 \pm 1,002$ \\
\hline \multirow[t]{2}{*}{$x B+x T$} & & $2,883 \pm 1,541$ & & $2,290 \pm 1,388$ \\
\hline & $\begin{array}{c}\left.{ }^{[} \mathrm{H}\right] \mathrm{TdR} \text { incorporation } \\
\text { Mean } \triangle C P M \pm S E M\end{array}$ & $\begin{array}{l}\text { Mean IgG secretion } \\
n g / m l \text { per } 7 d\end{array}$ & $\begin{array}{c}{\left[{ }^{3} \mathrm{H}\right] \mathrm{TdR} \text { incorporation }} \\
\text { Mean } \triangle C P M \pm S E M\end{array}$ & $\begin{array}{l}\text { Mean IgG secretion } \\
\text { ng/ml per } 7 d\end{array}$ \\
\hline$B+T$ & $21,010 \pm 2,632$ & $1,295 \pm 120$ & $18,943 \pm 3,458$ & $172 \pm 42$ \\
\hline$B+x T$ & $9,214 \pm 895$ & $1,987 \pm 317$ & $8,204 \pm 1,280$ & $236 \pm 66$ \\
\hline$B+T$ non $y$ & $24,977 \pm 3,006$ & $1,220 \pm 248$ & $22,338 \pm 3,379$ & $256 \pm 72$ \\
\hline$B+x T$ non-y & $13,877 \pm 1,342$ & $1,886 \pm 252$ & $11,923 \pm 2,301$ & $244 \pm 61$ \\
\hline$B+T \gamma$ & $3,384 \pm 1,626$ & $231 \pm 52$ & $3,139 \pm 1,200$ & $252 \pm 17$ \\
\hline$B+x T \gamma$ & $2,104 \pm 595$ & $163 \pm 45$ & $1,895 \pm 601$ & $192 \pm 22$ \\
\hline$B+(T$ non $\gamma+T \gamma)$ & $18,955 \pm 2,894$ & $685 \pm 150$ & $16,408 \pm 2,444$ & $260 \pm 41$ \\
\hline
\end{tabular}

$x=2000$ rad $x$-irradiation.

Ratios of co-culture: $\mathrm{B}: \mathrm{T}=1 \times 10^{5}: 2 \times 10^{5}, \mathrm{~T}$ non- $\gamma: \mathrm{T} \gamma=1 \times 10^{5}: 1 \times 10^{5}$.

* $\left[{ }^{3} \mathrm{H}\right]$ tritiated thymidine $(\mathrm{TdR})$ incorporation expressed as counts per minute per culture well. 
TABLE IV

Radiosensitivity of Myeloma and Normal T Helper and Suppressor Subset Function

\begin{tabular}{|c|c|c|c|c|c|}
\hline \multicolumn{3}{|c|}{ Composition of co-culture } & \multirow[b]{2}{*}{$\begin{array}{c}{\left[{ }^{3} \mathrm{H}\right] \mathrm{TdR} \text { incorporation }} \\
\text { Mean } \triangle \mathrm{CPM}\end{array}$} & \multirow[b]{2}{*}{$\begin{array}{c}\text { Mean IgG secretion } \\
\mathrm{ng} / \mathrm{ml} \text { per } 7 \mathrm{~d}\end{array}$} & \multirow{2}{*}{$\begin{array}{c}\begin{array}{c}\text { Percent change } \\
\text { in IgG secretion }\end{array} \\
\begin{array}{c}\text { Percent enhancement } \\
\text { after } x \text {-irradiation }\end{array}\end{array}$} \\
\hline \multicolumn{3}{|c|}{$\begin{array}{l}\text { Normal B + normal } \\
\text { T subsets }\end{array}$} & & & \\
\hline \multirow{3}{*}{$\begin{array}{l}10^{5} B+2 \times 10^{5} \\
10^{5} B+2 \times 10^{5}\end{array}$} & T non $\gamma$ & & $51,969 \pm 3,306^{*}$ & $1,136 \pm 192$ & - \\
\hline & $\mathrm{xT}$ non- $\gamma$ & & $17,382 \pm 1,492$ & $1,760 \pm 204$ & $+54.9 \%$ \\
\hline & & & & & $\begin{array}{l}\text { Percent suppression } \\
\text { by } \mathrm{T}_{\gamma} \text { cells }\end{array}$ \\
\hline \multirow{4}{*}{$\begin{array}{c}10^{5} \mathrm{~B}+10^{5} \mathrm{~T} \\
\text { non- } \gamma\end{array}$} & $+1 \times 10^{5}$ & $\mathbf{x T} \gamma$ & $44,171 \pm 3,100$ & $1,040 \pm 166$ & $8.4 \%$ \\
\hline & $+5 \times 10^{4}$ & $\mathrm{~T} \gamma$ & $47,940 \pm 2,809$ & $880 \pm 81$ & $22.5 \%$ \\
\hline & $+1 \times 10^{5}$ & $\mathrm{~T} \gamma$ & $31,297 \pm 1,486$ & $650 \pm 52$ & $42.8 \%$ \\
\hline & $+2 \times 10^{5}$ & $\mathrm{~T} \gamma$ & $24,537 \pm 2,108$ & $390 \pm 63$ & $65.7 \%$ \\
\hline \multicolumn{3}{|c|}{$\begin{array}{l}\text { Normal B + myeloma } \\
\text { T subsets }\end{array}$} & & & $\begin{array}{l}\text { Percent enhancement } \\
\text { after } x \text {-irradiation }\end{array}$ \\
\hline $10^{5} B+2 \times 10^{5}$ & T non- $\gamma$ & & $41,140 \pm 3,363$ & $1,312 \pm 123$ & - \\
\hline $10^{5} \mathrm{~B}+2 \times 10^{5}$ & $\mathrm{xT}$ non-y & & $13,342 \pm 1,892$ & $1,105 \pm 128$ & $-15.8 \%$ \\
\hline \multicolumn{3}{|c|}{$\begin{array}{c}\text { Normal B + myeloma } \\
\text { T subsets }\end{array}$} & & & $\begin{array}{l}\text { Percent suppression } \\
\text { by } \mathrm{T} y \text { cells }\end{array}$ \\
\hline \multirow{4}{*}{$\begin{array}{l}10^{5} \mathrm{~B}+10^{5} \mathrm{~T} \\
\text { non- } \gamma\end{array}$} & $+1 \times 10^{5}$ & $\mathrm{xT} \gamma$ & $43,457 \pm 3,211$ & $1,255 \pm 183$ & $6.8 \%$ \\
\hline & $+5 \times 10^{4}$ & $\mathrm{~T} \gamma$ & $36,663 \pm 2,776$ & $1,040 \pm 104$ & $20.7 \%$ \\
\hline & $+1 \times 10^{5}$ & $\mathrm{~T} \gamma$ & $29,595 \pm 1,764$ & $720 \pm 120$ & $45.1 \%$ \\
\hline & $+2 \times 10^{5}$ & $\mathrm{~T} \gamma$ & $25,172 \pm 1,285$ & $520 \pm 86$ & $60.4 \%$ \\
\hline
\end{tabular}

$\mathrm{x}, 2,000 \mathrm{rad} \mathrm{x}$-irradiation.

* Results expressed as means of four separate experiments \pm SEM.

$\left[{ }^{3} \mathrm{H}\right]$ tritiated thymidine $(\mathrm{TdR})$ incorporation expressed as counts per minute per culture well.

normal donors. Patient B lymphocytes, however, while demonstrating the normal cooperative blast responsiveness in co-culture with autologous irradiated $\mathrm{T}$ or $\mathrm{T}$ non- $\gamma$ cells, remained unable to differentiate into plasma cells, even in the presence of irradiated T non$\gamma$ cells. X-irradiation of the normal or MM T $\gamma$ subset did not substantially improve its complete lack of helper activity in either the blast or Ig secretion assay, confirming the absence of cells with radioresistant helper function within this subpopulation

Immunoregulatory capacity of myeloma $T$ cell subsets on normal B cell function. As a next step in analyzing $\mathrm{T}$ helper and suppressor functional capacity in MM, we examined the ability of isolated $\mathrm{T} \gamma$ and $\mathrm{T}$ non- $\gamma$ subsets from myeloma patients to augment or depress normal allogeneic $B$ cell differentiation. Results obtained in four myeloma patients and in four normal controls are shown in Table IV. The normal T non- $\gamma$ subset provides helper function for autologous B cell DNA synthesis and prior irradiation of this subset results in $>50 \%$ increment in IgG secretion. Ty cells, in contrast, suppress both blast responsiveness and IgG secretion of co-cultured B and T non- $\gamma$ cells in a dose-dependent fashion. Myeloma $T$ non- $\gamma$ cells co-cultured with allogeneic normal B cells provide radioresistant helper áctivity that is equal to autologous $T$ cells. Similarly, myeloma T $\gamma$ cells can suppress normal B cell responses in the presence of the myeloma $T$ non- $\gamma$ subset and this suppressor activity is radiosensitive to 2,000 rad. A marked distinction between myeloma and normal $\mathrm{T}$ helper function is demonstrated, however, by irradiation of the $\mathrm{T}$ non- $\gamma$ population. As previously described for total myeloma $\mathrm{T}$ cell populations, $x$-irradiation of the $T$ non- $\gamma$ subset also fails to produce the normal increment in IgG secretion and, in these four patients, resulted in a small decrease in mean IgG production. These results support those obtained with unfractionated $T$ and $B$ populations in the 13 original patients and suggest that, while $T$ helper and $\mathrm{T} \gamma$ suppressor cell function are intact, there is an additional radiosensitive $\mathrm{T}$ suppressor subset that is functionally deficient in multiple myeloma and that lacks $\mathrm{Fc}$ receptors for IgG. In order to confirm that patients with multiple myeloma are de- 
TABLE V

Con A-inducible Suppressor Activity by Normal and Myeloma T Cell Subsets

\begin{tabular}{|c|c|c|c|}
\hline \multicolumn{2}{|c|}{ Composition of co-culture } & \multirow[b]{2}{*}{ Mean IgG secretion } & \multirow[b]{2}{*}{$\begin{array}{l}\text { Percent suppression of } \\
\text { IgG synthesis }\end{array}$} \\
\hline $\begin{array}{c}\text { Normal } \\
\text { donor cells }\end{array}$ & $\begin{array}{l}\text { Con A-induced } \\
\text { suppressor population }\end{array}$ & & \\
\hline $\begin{array}{l}1 \times 10^{5} \mathrm{~B}+ \\
1 \times 10^{5} \mathrm{Tx}\end{array}$ & $\begin{array}{l}+1 \times 10^{5} \mathrm{nT} \text { Controls } \\
\quad \text { cultured without Con A } \\
+1 \times 10^{5} \mathrm{nT} \\
+1 \times 10^{5} \mathrm{nT} \text { non- } \gamma \\
+1 \times 10^{5} \mathrm{nTx} \\
+1 \times 10^{5} \mathrm{MM}-\mathrm{T} \\
+1 \times 10^{5} \mathrm{MM}-\mathrm{T} \text { non- } \gamma \\
+1 \times 10^{5} \mathrm{MM}-\mathrm{Tx}\end{array}$ & $\begin{array}{r}n g / m l \text { per } 7 d \\
\\
2,130 \pm 384 \\
388 \pm 126 \\
427 \pm 183 \\
2,359 \pm 366 \\
1,978 \pm 236 \\
1,921 \pm 192 \\
2,077 \pm 243\end{array}$ & $\begin{array}{r}\% \\
- \\
82 \\
80 \\
0 \\
8 \\
10 \\
2\end{array}$ \\
\hline
\end{tabular}

$\mathrm{x}, 2,000 \mathrm{rad} \mathrm{x}$-irradiation. Where indicated, suppressor cell populations were irradiated prior to Con A activation. Results expressed as means of four separate experiments \pm SEM. Suppressor cells were incubated $48 \mathrm{~h}$ in the presence of $5 \mu \mathrm{g} / \mathrm{ml}$ Con $A$ and subsequently with $25 \mu \mathrm{g} / \mathrm{ml}$ mitomycin-C as described in the text.

ficient in radiosensitive $T$ non- $\gamma$ subset function, we have also examined the ability of total patient $\mathrm{T}$ and $\mathrm{T}$ non- $\gamma$ cells to generate suppressor activity for IgG synthesis in the presence of Con A as shown in Table $\mathrm{V}$. Co-cultures of normal B and irradiated normal T cells were used as an indicator system and total $\mathrm{T}$ cells and the $T$ non- $\gamma$ subset from four patients and four normal donors were activated in the presence of $5 \mu \mathrm{g} / \mathrm{ml}$ Con A for $48 \mathrm{~h}$ and subsequently treated with $25 \mu \mathrm{g} / \mathrm{ml}$ mitomycin-C. When Con A-activated normal $T$ or normal $T$ non- $\gamma$ cells were added to $B+T x$ co-cultures on day 0 , IgG secretion was inhibited by $80 \%$. In contrast, MM-T or MM-T non- $\gamma$ cells suppressed subsequent IgG secretion by only $10 \%$ or less. Irradiation of normal T cells with 2,000 rad prior to Con$A$ activation abrogated the mitogen-induced generation of suppressor activity confirming the radiosensitivity of this suppressor population's activity. MM-T cells from these four patients were unaffected by a 48-h culture in the absence of Con $A$ and lacked significant suppressor activity for Ig secretion.

\section{DISCUSSION}

A variety of in vitro immune functional abnormalities have been described in both murine and human systems in an effort to explain the inability of myeloma B cells to differentiate into plasma cells capable of secreting Ig, either in response to specific antigens or nonspecific mitogens. Using a murine plasmacytoma model, Zolla et al. $(4,6)$ demonstrated that although cells with antigen receptors are apparently normal in number and function, both primary and secondary immune responses are depressed in direct correlation with tumor size. Using a PWM-driven co-culture assay analogous to that described here, Broder et al. (11) demonstrated decreased Ig synthesis by normal donor lymphocytes in the presence of adherent cells but not of $T$ cells from myeloma patients. They suggested, therefore, that impaired Ig synthesis by patient B cells was secondary to increased activity by a monocyte suppressor population. Normal donor adherent cells may, however, also suppress B cell differentiation to an equal degree in this assay (13). Paglieroni and MacKenzie $(14,15)$ demonstrated a significant amount of suppressor activity in myeloma lymphocyte populations that were essentially free of adherent or phagocytic cells. In their studies the suppressor activity appeared to be mediated by lymphocytes bearing Fc receptors that were present following carbonyl-iron depletion of phagocytic/adherent cells. Although they suggested that this suppressor subset may represent a nonphagocytic monocytoid cell such as that described by Hayward and Greaves (23), other possible candidates include $\mathrm{FcR}^{+}$null lymphocytes or $\mathrm{T} \gamma$ lymphocytes, which have been suggested to represent the same or similar cell subsets at different stages of differentiation or function $(21,24)$. The suppression of MM B cell differentiation appears distinct from the depressed Ig secretion seen in vivo and in vitro with leukemic B cell populations from most patients with chronic lymphocytic leukemia. In those patients neither B cell proliferation nor subsequent Ig secretion occur unless patients are in remission (25) indicating an intrinsic functional deficit of the circulating leukemic population. In contrast, our data indicate that the peripheral $B$ cell population of myeloma patients can proliferate in response to PWM and in the 
presence of autologous irradiated $\mathrm{T}$ cells but subsequently fails to differentiate and secrete Ig. This further supports the notion of a functional increase in suppressor activity $(14,15)$, which appears to operate at a later point in $\mathrm{B}$ cell differentiation than DNA synthesis.

The results presented here argue strongly against an abnormality of either $\mathrm{T} \gamma$ suppressor activity or $\mathrm{T}$ non- $\gamma$ helper function in MM. Both T non- $\gamma$ helper and T $\gamma$ suppressor function were intact in untreated patients despite the inability of autologous patient $\mathrm{E}^{-}$cells (which contained $\mathrm{FcR}^{+}$null cells as well as $\mathrm{sIg}^{+}$ cells) to differentiate into plasma cells. In an effort to examine myeloma suppressor function by a parameter independent of $\mathrm{T} \gamma$ subset interaction with antigenantibody complexes, we have also used the functional sensitivity of $\mathrm{T}$ suppressor activity to low-dose $\mathrm{x}$-irradiation and Con A-induction of suppressor activity. Radioresistance of $\mathrm{T}$ cell help and sensitivity of $\mathrm{T}$ suppressor function to low doses of $\mathrm{x}$-irradiation has been described for total T cells (22) as well as fractionated $\mathrm{T} \gamma$ cells (19). The failure of the irradiated patient total $\mathrm{T}$ population to demonstrate the expected increment in help suggested either a functional or proportional T $\gamma$ deficit in MM. In the experiments described here, the $T$ non- $\gamma$ subset from normal donors demonstrated an $x$-ray induced increment in IgG secretion equal to total irradiated T cells. Although this might possibly be explained by a failure to totally deplete $\mathrm{T}$ cells with IgG receptors, it seems highly improbable that the $2-3 \%$ of contaminating $\mathrm{T} \gamma$ cells detected after separation could account for the observed $50 \%$ increment in helper activity following irradiation or for Con A-inducible suppressor activity within the $\mathrm{T}$ non- $\gamma$ subset. The presence of radiosensitive suppressor cells in the $\mathrm{T}$ non- $\gamma$ fraction has been previously described (26) and although both the $\mathrm{T} \gamma$ and $\mathrm{T}$ non- $\gamma$ subsets contain suppressor activity, the Con A-inducible $\mathrm{T}$ suppressor cell defined phenotypically with monoclonal antibodies lacks Fc receptors for IgG (24).

It appears more likely, therefore, that help and suppresssion cannot be ascribed to mutually exclusive $\mathrm{T}$ cell subsets based on the cellular expression of a particular class of $\mathrm{Fc}$ receptor. Pichler et al. (27) have previously demonstrated the modulation of $\mathrm{T} \gamma$ to $\mathrm{T} \mu$ cells following interaction with immune complexes and suggested that expression of a given receptor might reflect an activational state rather than a unique functional subset analogous to murine $T$ cell subsets defined by alloantisera $(28,29)$. Our data are consistent with this hypothesis and provide evidence that human $\mathrm{T}$ suppressor cells are indeed heterogeneous with respect to surface $F c$ receptors for IgG and IgM.
Sensitivity to both low-dose irradiation and to corticosteroids in vitro appears to be a more uniform characteristic of human suppressor $T$ cells in $B$ cell differentiation assays than does the presence of receptors for IgG $(22,30,31)$ suggesting the necessity for DNA synthesis as a prerequisite to suppressor function by at least some $\mathrm{T}$ cell subsets. Similar results have been obtained in murine $T$ suppressor experiments (32) although this conclusion remains controversial, perhaps because of the wide variety of assays used in measuring suppression. Our finding that total myeloma $\mathrm{T}$ populations as well as the MM T non- $\gamma$ subset fail to demonstrate an $\mathrm{x}$-ray induced increment in help or Con A-inducible suppressor activity supports the conclusion that the normal $\mathrm{T}$ non- $\gamma$ subpopulation contains prosuppressor $\mathrm{T}$ cells that are functionally deficient in myeloma patients. Although a reduction in total $\mathrm{T}$ suppressor activity could result from a proportional decrease in circulating $\mathrm{T} \gamma$ cells, this would not explain the distinction between the normal and patient $\mathrm{T}$ non- $\gamma$ subpopulations. The dose-dependent suppressor effects obtained with the myeloma $\mathrm{T} \gamma$ subset on allogeneic normal B cells clearly demonstrate that this suppressor deficiency is not due to a functional abnormality in those $\mathrm{T}$ cells with Fc-IgG receptors, although the proportional decrease in $\mathrm{T} \gamma$ cells could be contributory to the absence of irradiation-induced increments of helper activity in total myeloma $T$ populations. Other possible mechanisms that might play a role in explaining the absence of the radiationinduced increment in IgG secretion described also appear unlikely. The arguments that myeloma $\mathrm{T}$ helper cells are more radiosensitive or that MM-T non- $\gamma$ suppressors more radioresistant than their normal counterparts appear to be countered by our demonstration that Con A-inducible suppressor activity is also deficient in myeloma. Moreover, the results cannot, apparently, be explained in postulating a quantitative decrease in patient helper $\mathrm{T}$ cells leading to a relatively greater effect of $\mathrm{x}$-irradiation on MM-T cell help than on normal $T$ cells and thus to an absence of the expected augmentation of IgG synthesis. Since patient $\mathrm{T}$ cell helper activity was equivalent to normal help even at very low T:B cell ratios, it would appear that $\mathrm{T}$ helper cells are present in equal proportions in both myeloma and normal $\mathrm{T}$ cell populations.

Our findings are consistent with previous descriptions of immunoregulatory cell function in $\mathrm{MM}$ $(11,13,14,15)$ and provide additional data delineating the function of helper and suppressor $T$ cells in this malignancy. $T$ helper function for polyclonal Ig secretion is clearly intact despite the suppressed B cell function. The suppressor activity of the $\mathrm{T} \gamma$ subset is likewise normal despite a minor decrease in the numbers of circulating $\mathrm{T} \gamma$ cells. Of interest, however, is 
the clear demonstration of radiosensitive suppressor activity by the T non- $\gamma$ subset, which is proportionally greater than the contribution of suppression by $\mathrm{T} \gamma$ cells in normal individuals and virtually absent in myeloma patients. These results provide functional confirmation for those of Reinherz et al. (24) who have indicated that the normal peripheral $\mathrm{T}$ non- $\gamma$ population contains both Con A-inducible suppressor cells and inducer (helper) $\mathrm{T}$ cells as defined phenotypically by monoclonal antibodies to human $T$ cell subsets. For functional regulation of $\mathrm{B}$ cell differentiation the $\mathrm{T} \gamma$ subset in both normal individuals and myeloma patients evidently contains suppressor cells that do not require Con $\mathrm{A}$ activation. The $\mathrm{T} \gamma$ subset, however, lacks the helper activity of the $\mathrm{T}$ non- $\gamma$ subset. Whether this subset is a monocytoid cell, a true thymus-derived lymphocyte, or an $\mathrm{Fc}^{+}$null cell remains uncertain $(21,23,24,33)$ although its suppressor sensitivity to $2,000 \mathrm{rad} x$-irradiation makes it functionally more analogous to Con A-inducible T non$\gamma$ and $\mathrm{T} \gamma$ suppressors than to adherent cells capable of suppressing B cell differentiation in a similar assay system (13). The explanation for abnormalities of suppressor cell function in $\mathrm{MM}$ also remains elusive. The $T$ suppressor dysfunction demonstrated here may represent a normal compensation of the regulatory network in response to increased activity by non- $T$ suppressor populations or, alternatively, the immunopathology of multiple myeloma may actually involve regulatory $\mathrm{T}$ cell subsets.

\section{ACKNOWLEDGMENTS}

This study was supported in part by American Cancer Society grants IN-545-15 and IM-254A, U. S. Public Health Service grant CA-5834 from the National Cancer Institute, and a grant from the Leukemia Research Foundation, Inc.

\section{REFERENCES}

1. Fahey, J. L., R. Scoggins, J. P. Utz, and C. F. Szwed. 1963. Infection, antibody response and gamma globulin components in multiple myeloma and macroglobulinemia. Am. J. Med. 39: 698-707.

2. Cone, L., and J. J. Uhr. 1961. Immunological deficiency disorders associated with chronic lymphocytic leukemia and multiple myeloma. J. Clin. Invest. 43: 2241-2248.

3. Salmon, S. E. 1974. Paraneoplastic syndromes associated with monoclonal lymphocytes and plasma cell proliferation. Ann. N. Y. Acad. Sci. 230: 228-239.

4. Zolla, S., D., Naor, and P. Tanapatchaiyapong. 1974. Cellular basis of immunodepression in mice bearing plasmacytomas. J. Immunol. 112: 2068-2076.

5. Kolb, J., S. Arrian, and S. Zolla-Pazner. 1977. Suppression of the humoral immune response by plasmacytomas: mediation by adherent mononuclear cells. J. Immunol. 118: 702-702.

6. Zolla, S. 1972. The effect of plasmacytomas on the immune response of mice. J. Immunol. 108: 1039-1048.

7. Krakauer, R. S., W. Strober, and T. A. Waldmann. 1977.
Hypogammaglobulinemia in experimental myeloma: the role of suppressor mononuclear phagocytes. J. Immunol. 118: $1385-1390$.

8. Boopalam, N., V. Yakulis, N. Costea, and P. Heller. 1972. Surface immunoglobulins on circulating lymphocytes in mouse plasmactyoma. II. The influence of plasmacytoma RNA on surface immunoglobulins of lymphocytes. Blood. 39: 465-471.

9. Salmon, S. E. 1973. Immunoglobin synthesis and tumor kinetics of multiple myeloma. Semin. Hematol. 10: 135-147.

10. Tanapatchaiyapong, P., and S. Zolla. 1974. Humoral immunosuppressive substance in mice bearing plasmacytomas. Science (Wash. D. C.). 186: 748-750.

11. Broder, S., R. Humphrey, M. Durm, M. Blackman, B. Meade, C. Goldman, W. Strober, and T. A. Waldmann. 1975. Impaired synthesis of polyclonal (non-paraprotein) immunoglobulins by circulating lymphocytes from patients with multiple myeloma: role of suppressor cells. N. Engl. J. Med. 293: 887-892.

12. Kennard, J., and S. Zolla-Pazner. 1980. Origin and function of suppressor macrophages in myeloma. J. Immunol. 124: 268-273.

13. Knapp, W., and G. Baumgartner. 1978. Monocyte-mediated suppression of human B lymphocyte differentiation in vitro. J. Immunol. 121: 1177-1183.

14. Paglieroni, T., and M. R. MacKenzie. 1977. Studies on the pathogenesis of the immune defect in multiple myeloma. J. Clin. Invest. 59: 1120-1133.

15. Paglieroni, T., and M. R. MacKenzie. 1980. Multiple myeloma: an immunologic profile. III. Cytotoxic and suppressive effects of the EA rosette-forming cell. $J$. Immunol. 124: 2563-2570.

16. Kaplan, M. E., and C. Clark. 1974. An improved rosetting assay for detection of human T lymphocytes. J. Immunol. Methods. 5: 131-135.

17. Gold, E. R., and H. H. Fudenberg. 1967. Chromic chloride: a coupling reagent for passive hemagglutination reactions. J. Immunol. 99: 859-866.

18. Ozer, H., A. J. Strelkauskas, R. T. Callery, and S. F. Schlossman, 1979. A rapid method for the isolation of human peripheral null lymphocytes. Cell. Immunol. 45: 334-343.

19. Moretta, L., S. R. Webb, C. E. Grossi, P. M. Lydyard, and M. D. Cooper. 1977. Functional analysis of two human T-cell subpopulations: help and suppression of B cell responses by $T$ cells bearing receptors for $\operatorname{IgM}(T \mu)$ or IgG (Ty). J. Exp. Med. 146: 184-200.

20. Gailani, S., B. K. Seon, A. Nussbaum, E. S. Henderson, and D. Pressman. 1977. Radioimmunoassay for myeloma idiotype. J. Natl. Cancer Inst. 58: 1553-1555.

21. Ozer, H., A. J. Strelkauskas, R. T. Callery, and S. F. Schlossman. 1979. The functional dissection of human peripheral null cells with respect to antibody-dependent cellular cytotoxicity and natural killing. Eur. J. Immunol. 9: $112-118$.

22. Siegal, F. P., and M. Siegal. 1977. Enhancement by irradiated $\mathrm{T}$ cells of human plasma cell production: dissection of helper and suppressor functions in vitro. $J$. Immunol. 118: 642-647.

23. Hayward, A. R., and M. B. Greaves. 1975. Identification of cells with monocyte markers in panhypogammaglobulinaemia. Scand. J. Immunol. 4: 563-570.

24. Reinherz, E. L., L. Moretta, M. Roper, J. M. Breard, M. C. Mingari, M. D. Cooper, and S. F. Schlossman. 1980. Human $T$ lymphocyte subpopulations defined by $F_{c}$ re- 
ceptors and monoclonal antibodies. J. Exp. Med. 151: 969-974.

25. Han., T., and B. Dadey. 1979. In vitro functional studies of mononuclear cells in patients with CLL. Evidence for functionally normal $\mathrm{T}$ lymphocytes and monocytes and abnormal B lymphocytes. Cancer (Phila.). 43: 109-117.

26. Hayward, A. R., L. Layward, P. M. Lydyard, L. Moretta, M. Dagg, and A. R. Lawton. 1978. Fc-receptor heterogeneity of human suppressor $\mathrm{T}$ cells. J. Immunol. 121: $1-5$.

27. Pichler, W. J., L. Lum, and S. Broder. Fc-receptors on human $\mathrm{T}$ lymphocytes, I. Transition of $\mathrm{T} \gamma$ to $\mathrm{T} \mu$ cells. J. Immunol. 121: 1540-1548.

28. Jandinski, J., H. Cantor, T. Tadakuma, D. L. Peavy, and C. W. Pierce. 1976. Separation of helper T cells from suppressor $\mathrm{T}$ cells expressing different Ly components. I. Polyclonal activation: suppressor and helper activities are inherent properties of distinct T-cell subclasses. J. Exp. Med. 143: $1382-1390$.

29. Cantor, H., F. W. Shen, and E. A. Boyse. 1976. Separation of helper cells from suppressor $\mathrm{T}$ cells expressing different Ly components. II. Activation by antigen: after immunization, antigen-specific suppressor and helper activities are mediated by distinct T-cell subclasses. $J$. Exp. Med. 143: 1391-1401.

30. Fauci, A. S., K. R. Pratt, and G. Whalen. 1977. Activation of human B lymphocytes. IV. Regulatory effects of corticosteroids on the triggering signal in the plaque-forming cell response of human peripheral blood B lymphocytes to polyclonal activation. J. Immunol. 119: 598-603.

31. Lobo, P. I., and C. E. Spencer. 1979. Inhibition of humoral and cell-mediated immune responses in man by distinct suppressor cell systems J. Clin. Invest. 63: 1157-1163.

32. Dutton, R. W. 1975. Suppressor T cells. Transplant. Rev. 26: $39-55$.

33. Shaw, S., W. J. Pichler, and D. L. Nelson. 1979. Fc receptors on human T-lymphocytes. III. Characterization of subpopulations involved in cell-mediated lympholysis and antibody-dependent cellular cytotoxicity.J. I mmunol. 122: 599-604. 